\title{
Gait speed and malnutrition in hospitalized patients and the quality of life of their caregivers
}

\author{
Velocidade de marcha e desnutrição em paciente hospitalizados e qualidade de vida de seus cuidadores \\ Velocidad de la marcha y desnutrición en pacientes hospitalizados y calidad de vida de sus cuidadores
}

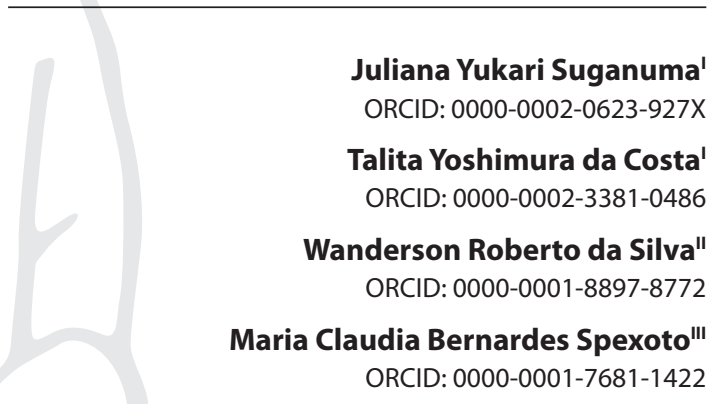

'Universidade Federal da Grande Dourados, Hospital Universitário. Dourados, Mato Grosso do Sul, Brazil. "Universidade Estadual Paulista Júlio de Mesquita Filho. Araraquara, São Paulo, Brazil. I"Universidade Federal da Grande Dourados. Dourados, Mato Grosso do Sul, Brazil.

How to cite this article: Suganuma JY, Costa TY, Silva WR, Spexoto MCB. Gait speed and malnutrition in hospitalized patients and the quality of life of their caregivers. Rev Bras Enferm. 2020;73(Suppl 5):e20190776. doi:http://dx.doi.org/10.1590/0034-7167-2019-0137-2019-0776

Corresponding author: Maria Claudia Bernardes Spexoto E-mail:mariaspexoto@ufgd.edu.br

EDITOR IN CHIEF: Antonio José de Almeida Filho ASSOCIATE EDITOR: Hugo Fernandes

Submission: $01-27-2020$

Approval: 05-24-2020

\begin{abstract}
Objective: To verify the age, nutritional status, and gait speed in hospitalized individuals, and their association with the quality of life of their caregivers. Methods: Observational cross-sectional study with 54 patients and their respective caretakers in a university hospital in the Brazilian Midwest. The analyses were carried out using the SPSS software, with $p<$ 0.05. Results: The Social Relations domain had the highest mean score $(71.45 \pm 18.64)$. The lowest score was in the Physical domain $(57.80 \pm 12.01)$. According to a subjective nutritional evaluation, $72.2 \%$ presented some degree of malnutrition. Most were classified with low gait speeds ( $82 \%)$. There was a significant correlation between age and the Physical and General Quality of Life domains. The Environment domain was significantly correlated to the gait speed. Conclusion: The age and the gait speed of the patient were related to the quality of life of the caregiver, but the nutritional state was not affected.

Descriptors: Caregivers; Quality of Life; Malnutrition; Nutritional Status; Frailty.
\end{abstract}

\section{RESUMO}

Objetivo: Verificar a relação da idade, estado nutricional e velocidade de marcha de indivíduos hospitalizados com a qualidade de vida de seus cuidadores. Métodos: Estudo observacional do tipo transversal com 54 pacientes e seus respectivos cuidadores em um hospital universitário da região Centro-Oeste do Brasil. Análises foram realizadas no programa SPSS considerando $p<0,05$. Resultados: O domínio Relações sociais obteve o escore médio mais elevado $(71,45 \pm 18,64)$ e o mais baixo foi do domínio Físico $(57,80 \pm 12,01)$. Segundo avaliação nutricional subjetiva, $72,2 \%$ apresentavam algum grau de desnutrição. A maioria foi classificada com baixa velocidade de marcha (82\%). Encontrou-se correlação significativa entre a idade e os domínios Físico e Qualidade de vida geral. O domínio Ambiente correlacionouse significativamente com a velocidade de marcha. Conclusão: A idade e a velocidade de marcha do paciente estiveram relacionadas com a qualidade de vida do cuidador, porém não encontramos impacto no estado nutricional.

Descritores: Cuidadores; Qualidade de Vida; Desnutrição; Estado Nutricional; Fragilidade.

\section{RESUMEN}

Objetivo: Verificar la relación de la edad, estado nutricional y velocidad de la marcha de indivíduos hospitalizados con la calidad de vida de sus cuidadores. Métodos: Estudio observacional del tipo transversal con 54 pacientes y sus respectivos cuidadores en un hospital universitario del Medio oeste de Brasil. Análisis han sido realizadas en el programa SPSS considerando $p<0,05$. Resultados: El dominio Relaciones sociales obtuvo la calificación media más elevada $(71,45 \pm 18,64)$ y la más baja ha sido del dominio Físico $(57,80 \pm 12,01)$. Segundo evaluación nutricional subjetiva, $72,2 \%$ presentaban alguno grado de desnutrición. La mayoría ha sido clasificada con baja velocidad de la marcha (82\%). Se encontró correlación significativa entre la edad y los dominios Físico y Calidad de vida general. El dominio Ambiente se ha correlacionado significativamente con la velocidad de marcha. Conclusión: La edad y la velocidad de la marcha del paciente han estado relacionadas con la calidad de vida del cuidador, pero no encontramos impacto en el estado nutricional.

Descriptores: Cuidadores; Calidad de Vida; Desnutrición; Estado Nutricional; Fragilidad. 


\section{INTRODUCTION}

Population aging has been a growing issue throughout the world and is a challenge for society. The World Population Prospects 2019: Highlights, published by the United Nations (UN), estimated, for 2019, that there would be 1 elder in each 11 people in the world; and the expectancy is that, up to 2050, this number will be 1 in 6 . Also, the number of 80-year-old or older individuals will triple from 2019 to $2015^{(1)}$.

The increased life expectancy, coupled with the natural aging process, means that many changes take place in the organism, and the likelihood of developing some type of chronic disease also increases. On the other hand, these factors may lead to a bigger number of frail individuals, thus increasing the number of elders who need long-term care ${ }^{(2)}$.

Frailty is a geriatric syndrome that takes place due to multifactorial changes that lead to homeostatic decline and unbalance. It is characterized by weight loss, diminution in strength, self-reported exhaustion, low performance in gait, and little physical activity ${ }^{(3)}$. A condition that frequently takes place simultaneously to this is malnutrition ${ }^{(4)}$, which continues being a health problem in developing countries. According to a systematic review involving 29,474 patients from 12 countries in Latin America, the prevalence rates for malnutrition vary from $40 \%$ to $60 \%$ in the moment of hospital admission ${ }^{(5)}$.comorbidities, Activities of Daily Living (ADL

Therefore, there should be an early and quality nutritional screening, aiming to choose the best course of action and to delineate an effective and individualized intervention plan ${ }^{(6)}$. To do so, in the hospital environment, the Subjective Global Assessment $(\mathrm{SGA})^{(7)}$ is considered to be the golden standard instrument, in addition to being widely used. Its latest version is generated by the patient and is called PG-SGA ${ }^{(8)}$.

To aid in the health assessment of the patient, the gait speed (GS) can be investigated, since it is a safe, fast, and reliable test. GS is a relevant clinical marker to find the functional state of the patient, especially in the case of elders. As a result of the process of aging itself and of the lack of physical activities, the functional status diminishes, which can culminate in the development of frailty and sarcopenia. Therefore, it is an important factor to be analyzed $^{(9-10)}$. The patients that are in a state of malnutrition and have a diminished GS can present worse complications and negative clinical outcomes, such as functional decline, falls, more hospitalizations and institutionalizations, more dependence on care from others, and an increased risk of death ${ }^{(11-14)}$.

Considering this framework of loss of independence, the image of the caregiver takes an important role. A caregiver is defined by the Practical Guide for the Caregiver ${ }^{(15)}$ as a relative or someone else they know who offers care to another subject with physical or mental limitations, being or not paid to do so. The act of caring goes beyond the simple fact of being responsible for one's hygiene, medication, and eating; it also involves spending time and offering company. Considering this, caregivers often change their own routines because of the individual that needs to be cared for. They restrict their social and sometimes even their professional lives, in addition to being exposed to both physical and emotional overloads ${ }^{(16)}$. As a result, this may have an impact in their own quality of life (QoL), in their relations with the elder ${ }^{(17)}$, and in the care they provide to the patient.
QoL is a multidimensional concept that involves different factors. Generally, it can be understood as the perception of individuals with regard to their own lives, depending on physical, psychological, environmental, and social aspects ${ }^{(18)}$. Therefore, considering the compromising factors to which the caregiver of a hospitalized patient is exposed, it is relevant to discover what is their perception regarding their own QoL.

As a result, would the nutritional status and the GS be relevant aspects of hospitalized individuals, and could these aspects be associated to QoL of their caregivers? This question can aid in the quality of the care offered, since caregivers with a better perception of their QoL may feel more apt and motivated to develop their functions and, as a result, contribute to the improvement of their clinical framework and to the recovery of the patient ${ }^{(19)}$.

\section{OBJECTIVE}

To verify the age, nutritional state, and gait speed in hospitalized individuals and their association with the quality of life of their caregivers.

\section{METHODS}

\section{Ethical aspects}

This study was approved by the Research Ethics Committee for Researches with Human Beings from the Universidade Federal da Grande Dourados. All participants signed the Free and Informed Consent Form (FICF). The research was in accordance to Resolution 466/2012 and its precepts for researches involving human beings.

\section{Design, period, and place of study}

This is an observational cross-sectional study, carried out from April to September 2019, in the Surgical and Medical Clinical Wards of the University Hospital from the Universidade Federal da Grande Dourados - UH/UFGD, in Dourados (MS).

\section{Population; criteria of inclusion and exclusion}

A non-probabilistic convenience sample was used. A total of 93 patients was invited, from both sexes, admitted in the surgical and clinical hospitalization wards, who had been there for up to 48 hours and were 20 years old or older. Only 73 of them agreed participating. From these, 54, those who had caregivers, were included in the research. It should be clarified that this study used a paired sample, which means that, whenever a patient was included in the sample, their caregiver also was.

The exclusion criteria were: patients under respiratory precautions, who were not walking, could not be evaluated in the first 48 hours of hospitalization, had cognitive deficits, neurodegenerative diseases or severe psychiatric disorders, who were younger than 20 years old, pregnant/puerperae/breastfeeding, and indigenous.

The sample of caregivers included all individuals, from both sexes, who were 20 years old or older, who were relatives or not, and who were the sole responsible parties for caring for the 
patient during the hospitalization period and, possibly, would also be so at home.

\section{Study protocol}

To characterize the total sample (patients and caregivers), the following variables were investigated: sex, age (complete years), marital status (single, married, widow/widower, and separated/ divorced), employment status (with or without a job), and social class. The Brazilian Criteria for Social Classification - ABEP was used to classify the individuals in social classes ${ }^{(20)}$.

To evaluate the QoL of the caregiver, the Portuguese version of the World Health Organization Quality of Life Instrument-Abbreviated version (WHOQOL-Bref) was used. It is a self-applicable questionnaire made up by two questions about general quality of life. The first is about the general self-perception about one's QoL, and second, about their health self-evaluation. The other items (24) are divided in four domains. The Physical domain involves items such as: pain, energy, sleep, mobility, activities of daily living, and work (items 3, 4, 10, 15, 16,17 , and 18). The questions in the Psychological domain refer to positive feelings, spirituality, focus, body image, self-esteem, and negative feelings (items $5,6,7,11,19$, and 26). The Social Relations domain is about relationships, sexual activity, and social support (items 20,21, and 22). And the Environment domain is about issues related to safety, how healthy the physical environment is, finances, information, leisure, place of residence, access to health services, and transportation (items $8,9,12,13,14,23,24$, and 25).

Therefore, the instrument is based on 26 items with responses distributed in a 5-point Likert scale, including: from very poor (1) to very good (5); very dissatisfied (1) to very satisfied (5); not at all (1) to extremely (5); and not at all (1) to an extreme amount (5). Three items in the scale have inverted score: To what extent do you feel that physical pain prevents you from doing what you need to do? (item 3); How much do you need any medical treatment to function in your daily life? (item 4); and How often do you have negative feelings? (item 26). The mean score indicates the perception of the QoL in each domain. The higher the score, the better the $\mathrm{QoL}^{(18,21)}$.

The items of the WHOQOL-Bref were processed according to recommendations from the WHOQOL group ${ }^{(21)}$. The score obtained in items 3,4 , and 26 was recoded $(1=5,2=4,3=3,4=2$, and $5=$ 1). The mean for each domain was calculated with scores varying from 0 to 100 , which were then multiplied by 4 , by -4 , and by $100 / 16$. It should be mentioned that this research received authorization from the World Health Organization (WHO) to use the WHOQOLBref. It should also be clarified that, although the questionnaire is self-applicable, this study chose to fill it in through an interview, to guarantee that all items in the instrument received responses.

The clinical variables of the patient, such as previous chronic diseases and the nursing ward where the patient was, were found through medical records and during the interview in the first 48 hours after admission.

The nutritional status of the patient was evaluated based on their Body Mass Index (BMI), calculated using the weight (Kg) and height $\left(\mathrm{m}^{2}\right)$, as well as the Patient Generated Subjective Global Assessment (PG-SGA). The BMI was classified according to the standards from the World Health Organization ${ }^{(22)}$ and from Lipschitz et al. ${ }^{(23)}$, for adults and elders, respectively. The study used a version of the PG-SGA that had been validated for Brazilian Portuguese ${ }^{(24)}$. The instrument is made up of two parts. The first is filled-in by the patient (with or without help from the caregiver); the second, by the health professional. At the end, the patient is characterized in three categories $(A=$ well nourished; $\mathrm{B}=$ suspected $/$ moderate undernourishment; or $\mathrm{C}=$ severe undernourishment), and a score is generated that defines the necessary nutritional interventions, according to the score $(0-1=$ no intervention needed at the moment; $2-3=$ counseling to the patient and their relatives; $4-8=$ requires nutritional intervention; and $\geq 9=$ urgent need for nutritional action to improve the symptoms $)^{(8)}$.

The GS $(\mathrm{m} / \mathrm{s})$ was evaluated during a 4-meter course, including 1 meter for acceleration and 1 meter for deceleration. The patients used a footwear they were used to and were instructed to walk at the speed they found normal. The time spent moving was marked by the examiner(25).

GS was used as a continuous variable with the cutoff point $\leq$ $0.8 \mathrm{~m} / \mathrm{s}$, meaning the patient had to traverse the path determined in $\leq 5$ seconds, a number recommended by the European Working Group Sarcopenia in Older People (EWGSOP2) as being the most sensible value to identify negative outcomes ${ }^{(10)}$.

\section{Analysis of results and statistics}

Initially, descriptive statistics were used. Continuous data were presented in means and standard-deviations; categorical data was presented in frequencies and percentages. In order to investigate the relations between age, nutritional state, and the GS of patients with the quality of life of their caretakers, Spearman's rank correlation was calculated and analyzed. Aiming to study and compare the mean scores of each WHOQOL-Bref domain, a Variance Analysis (ANOVA) was carried out. Considering the violation of the homoscedasticity assumption, the Welch correlation was used; Games-Howell's post-test was also used when this was the case. The tests were considered significant when $p$ $<0.05$. The analyses were carried out in the software IBM SPSS Statistics (v. 22, SPSS An IMB Company, Chicago, IL).

\section{RESULTS}

In Table 1, one can find the characteristics of the sample studied.

The sample of the group of caretakers was made up of 54 individuals, with a mean age of $48.96 \pm 13.71$ years. Most participants were female $(79.6 \%)$, married $(57.4 \%)$, employed $(57.7 \%)$ and belonging to the social class C (61.1\%).

From the 54 patients, most were women $(n=28,51.9 \%)$. Their mean age was $67.48 \pm 10.04$ years, $55.6 \%$ had been admitted to the surgical clinic, most $(77.8 \%)$ were elderly and had from one to three chronic diseases (77.8\%). With regard to the indicator BMI, that of $48.1 \%(n=26)$ was adequate; when evaluated through the PG-SGA, $48.1 \%(n=26)$ had a score of 9 or more, that is, urgently required some type of nutritional intervention. $72.2 \%(n=39)$ presented some level of malnutrition (categories $B$ and $C$ ). The mean gait speed of the patients was $9.25 \pm 4.32$, with a minimum of 2.38 and a maximum of 23.05 seconds. Most were classified as having a low speed gait (82\%) 
Table 1 - Characterization of the participants of the study

\begin{tabular}{ll}
\hline Variable & Total \\
& $\mathbf{n}(\%)$ \\
\hline
\end{tabular}

Caregiver

Sex

Male

Female

Marital Status

Married

Single

Widow/widower

Separated/divorced

Employment status

No

Yes

Social class

A

B

$\mathrm{D}$ and $\mathrm{E}$

Patient

Sex

Male

Female

Stage of life

Adult ( $<60$ years old)

Elder ( $\geq 60$ years old)

Marital Status

Married

Single

Widow/widower

Separated/divorced

Employment status

No

Yes

Social class*

A

B

C

$D$ and $E$

Chronic diseases

None

1 to 3

4 or more

Wards

Surgical

Clinical

Body Mass Index (BMI)

Low weight

Adequate

Excess Weight

PG-SGA score

0-1

$2-3$

4-8

$\geq 9$

PG-SGA classification

Well nourished $(A)$

Moderately malnourished (B)

Severely malnourished (C)

Note: PG-SGA: Patient Generated Subjective Global Assessment; * Mean household income: $A$ $=R \$ 25,554.33 ; B=R \$ 5,641.64 a 11,279.14 ; C=R \$ 1,748.59 a$ 3,085.48; $D$ and $E=R \$ 719.81$

Table 2 presents the general distribution of the answers the caregivers gave to the WHOQOL-Bref. In the self-evaluation of their general QoL, most caregivers found it to be good (53.8\%). Regarding satisfaction with health, $50.9 \%(n=27)$ were satisfied.
When questioned on physical pain, $37 \%(n=20)$ of caregivers stated that this factor prevents them from doing daily life activities, while $41.5 \%(n=22)$ are under some medical treatment. However, they are satisfied (48.1\%) with their capacity for work.

When asked about how much meaning their lives have, 52.9\% (n $=28$ ) answered "a lot". Regarding the frequency of negative feelings, $44.4 \%(n=24)$ feel them frequently; and $20.4 \%(n=11)$ always feel them.

Regarding their satisfaction with personal relations, sexual lives, and with the support received from friends and relatives, the percentage of caregivers satisfied was $42.6 \%, 51.9 \%$, and $53.7 \%$, respectively.

Regarding the Environment domain, containing questions about safety, most (63\%) reported being quite satisfied, although $29.6 \%$ reported few opportunities for leisure.

Table 3 shows the mean scores for the sample of caregivers and the comparison between the Physical,Psychological, Social Relations, Environment, and General quality of life scores they reached in the WHOQOL-bref.

Table 2 - Frequencies of the responses given by caregivers to the items of the World Health Organization Quality of Life-Abbreviated version (WHOQOL-Bref)

\begin{tabular}{|c|c|c|c|c|c|c|c|c|c|c|}
\hline \multirow{2}{*}{ Questions } & \multicolumn{2}{|r|}{1} & \multicolumn{2}{|c|}{2} & \multicolumn{2}{|r|}{3} & \multicolumn{2}{|c|}{4} & \multicolumn{2}{|c|}{5} \\
\hline & $\mathbf{n}$ & $\%$ & $\mathbf{n}$ & $\%$ & $\mathbf{n}$ & $\%$ & $\mathbf{n}$ & $\%$ & $\mathbf{n}$ & $\%$ \\
\hline $\begin{array}{l}1 \text { General quality of life self- } \\
\text { perception }\end{array}$ & - & - & - & - & 16 & 30.8 & 28 & 53.8 & 8 & 15.4 \\
\hline 2 Health self-evaluation & 1 & 1.9 & 5 & 9.4 & 12 & 22.6 & 27 & 50.9 & 8 & 15.1 \\
\hline 3 Pain (physical) & 3 & 5.6 & 9 & 16.7 & 9 & 16.7 & 13 & 24.1 & 20 & 37.0 \\
\hline 4 Medical treatment & 3 & 5.7 & 13 & 24.5 & 9 & 17.0 & 6 & 11.3 & 22 & 41.5 \\
\hline 5 Positive feelings & 3 & 5.6 & 11 & 20.4 & 16 & 29.6 & 19 & 35.2 & 5 & 9.3 \\
\hline 6 Spirituality & - & - & 3 & 5.7 & 7 & 13.2 & 28 & 52.8 & 15 & 28.3 \\
\hline 7 Concentration & 1 & 1.9 & 4 & 7.4 & 21 & 38.9 & 23 & 42.6 & 5 & 9.3 \\
\hline 8 Safety & 2 & 3.7 & 3 & 5.6 & 10 & 18.5 & 34 & 63.0 & 5 & 9.3 \\
\hline $\begin{array}{l}9 \text { How healthythe physical } \\
\text { environment is }\end{array}$ & 6 & 11.3 & 1 & 1.9 & 13 & 24.5 & 25 & 47.2 & 8 & 15.1 \\
\hline 10 Energy & 1 & 1.9 & 6 & 11.1 & 18 & 33.3 & 17 & 31.5 & 12 & 22.2 \\
\hline nage & 2 & 3.8 & 4 & 7.5 & 12 & 22.6 & 11 & 20.8 & 24 & 45.3 \\
\hline 12 Fina & 3 & 5.6 & 12 & 22.2 & 30 & 55.6 & 5 & 9.3 & 4 & 7.4 \\
\hline 13 Information & 4 & 7.5 & 3 & 5.7 & 19 & 35.8 & 21 & 39.6 & 6 & 11.3 \\
\hline $14 \mathrm{~L}$ & 9 & 16.7 & 16 & 29.6 & 12 & 22.2 & 12 & 22.2 & 5 & 9.3 \\
\hline 15 Mobility & 1 & 2.0 & 3 & 5.9 & 6 & 11.8 & 13 & 25.5 & 28 & 54.9 \\
\hline $16 \mathrm{~S}$ & 1 & 1.9 & 8 & 14.8 & 16 & 29.6 & 17 & 31.5 & 12 & 22.2 \\
\hline $17 \mathrm{D}$ & 3 & 5.6 & 5 & 9.3 & 14 & 25.9 & 25 & 46.3 & 7 & 13.0 \\
\hline $18 V$ & 5 & 9.3 & 3 & 5.6 & 11 & 20.4 & 26 & 48.1 & 9 & 16.7 \\
\hline $19 \mathrm{~S}$ & 2 & 3.7 & 1 & 1.9 & 15 & 27.8 & 25 & 46.3 & 11 & 20.4 \\
\hline $20 \mathrm{R}$ & - & - & 2 & 3.7 & 12 & 22.2 & 23 & 42.6 & 17 & 31.5 \\
\hline 215 & 9 & 16.7 & 2 & 3.7 & 8 & 14.8 & 28 & 51.9 & 7 & 13.0 \\
\hline $22 \mathrm{~S}$ & - & - & 3 & 5.6 & 4 & 7.4 & 29 & 53.7 & 18 & 33.3 \\
\hline $23 \mathrm{~F}$ & - & - & 4 & 7.5 & 8 & 15.1 & 26 & 49.1 & 15 & 28.3 \\
\hline services & 2 & 3.7 & 2 & 3.7 & 14 & 25.9 & 25 & 46.3 & 11 & 20.4 \\
\hline rtation & - & - & 4 & 7.4 & 5 & 9.3 & 29 & 53.7 & 16 & 29.6 \\
\hline $26 \mathrm{Ne}$ & 5 & 9.3 & 5 & 9.3 & 9 & 16.7 & 24 & 44.4 & 11 & 20.4 \\
\hline \multirow{2}{*}{\multicolumn{11}{|c|}{$\begin{array}{l}\text { Note: WHOQOL-bref response options: from very poor (1) to very good (5); very dissatisfied (1) } \\
\text { to very satisfied (5); not at all (1) to extremely (5); and not at all (1) to an extreme amount (5). } \\
\text { Table } 3 \text { - Mean scores received by caregivers and comparison between } \\
\text { the score they achieved in the domains of the World Health Organization } \\
\text { Quality of Life-Abbreviated version (WHOQOL-Bref) }\end{array}$}} \\
\hline & & & & & & & & & & \\
\hline \multicolumn{3}{|l|}{ Domains } & \multicolumn{8}{|c|}{ Mean \pm Standard Deviation* } \\
\hline \multicolumn{5}{|l|}{ Physical } & \multicolumn{6}{|c|}{$57.80 \pm 12.01^{\mathrm{a}}$} \\
\hline \multicolumn{5}{|l|}{ Psychological } & \multicolumn{6}{|c|}{$62.03 \pm 13.43^{a}$} \\
\hline \multicolumn{5}{|l|}{ Social relations } & \multicolumn{6}{|c|}{$71.45 \pm 18.64^{b}$} \\
\hline \multicolumn{5}{|l|}{ Environment } & \multicolumn{6}{|c|}{$62.73 \pm 13.81^{\mathrm{a}}$} \\
\hline \multicolumn{5}{|l|}{ General QoL } & \multicolumn{4}{|c|}{$68.51 \pm 17.46$} & & \\
\hline
\end{tabular}

Note: ${ }^{a, b}$ Equal letters indicate statistical similarity. 
Table 4 - Correlation between the Physical, Psychological, Social Relations, Environment, and General Quality of Life domains and the variables age, nutritional status, and gait speed of the patients

\begin{tabular}{lccccccccccc}
\hline Variables & \multicolumn{2}{c}{$\begin{array}{c}\text { Physical } \\
\text { domain }\end{array}$} & \multicolumn{2}{c}{$\begin{array}{c}\text { Psychological } \\
\text { domain }\end{array}$} & \multicolumn{2}{c}{$\begin{array}{c}\text { Social } \\
\text { Relations } \\
\text { domain }\end{array}$} & \multicolumn{2}{c}{$\begin{array}{c}\text { Environment } \\
\text { domain }\end{array}$} & \multicolumn{2}{c}{$\begin{array}{c}\text { General } \\
\text { QoL domain }\end{array}$} \\
& $\rho$ & $p$ & $\rho$ & $p$ & $\rho$ & $p$ & $\rho$ & $p$ & $\rho$ & $p$ \\
\hline Age (years) & $-0.412^{*}$ & 0.002 & -0.120 & 0.386 & -0.187 & 0.175 & -0.112 & 0.421 & $-0.296^{*}$ & 0.030 \\
BMI (kg/m ${ }^{2}$ ) & 0.031 & 0.826 & 0.015 & 0.914 & -0.010 & 0.945 & 0.111 & 0.422 & 0.056 & 0.686 \\
PG-SGA score & -0.259 & 0.059 & 0.136 & 0.326 & -0.122 & 0.381 & -0.120 & 0.388 & -0.124 & 0.370 \\
GS (seconds) & -0.134 & 0.353 & 0.051 & 0.723 & -0.061 & 0.674 & $-0.312^{*}$ & 0.027 & -0.175 & 0.224
\end{tabular}

Note: Spearman's rho ( $\rho)$; P-value ( $p)$; ${ }^{*} p<0.05 ;$;MI: Body Mass Index; PG-SGA: Patient Generated Subjective Global Assessment; GS: gait speed.

The highest score for quality of life was in the Social Relations domain, with $71.45 \pm 18.64$; the most compromised domain was the Physical one, with $57.80 \pm 12.01$. When the mean scores were compared, significant differences were found between the domains $(F=116.740$; test power $=1.000 ; p<0.001)$.

Table 4 shows the correlation between the Physical, Psychological, Social Relations, Environment, and General Quality of Life domains and the variables "age", "nutritional status", and "gait speed of the patients".

There was a significant correlation between age and the Physical ( $\rho=-0.412 ; p=0.002)$ and General QoL $(\rho=-0.296 ; p$ $=0.030$ ) domains. Furthermore, the Environment domain had a significant correlation with the gait speed as evaluated by the test of walking 4 meters $(\rho=0.312 ; p=0.027)$.

\section{DISCUSSION}

This study aimed to contribute for the literature with regards to identifying that the decline in gait speed is one of the characteristics of the patient related to the quality of life of the caregiver, especially with aspects connected to the environment. In addition, we found that malnutrition, although in its peak it leads to negative outcomes to the patient, was not, in this study, associated with the quality of life of the caregiver, even though most patients were found to be malnourished. Still, we found that the age of the patient is a variable connected to the general QoL of the caregiver and to their physical aspect, since the population of this study is mostly made up of elders, requiring more attention and care.

The predominance of females in this study may be explained by the fact that the act of caring is naturalized as something that is exercised by women, and is socially seen as a female daily activity, perpetuating the idea that domestic responsibilities should be attributed to women. Similarly, men are considered to be responsible for political and economic tasks and, when in the context of care, are seen as secondary caregivers, being responsible for indirect activities such as transporting and assuming the financial organization of the person being cared for ${ }^{(26)}$.

Most patients and caregivers in this study were classified as belonging to the social class $C$. In an epidemiological study by Alexandre et al. ${ }^{(27)}$, which evaluated 1,413 elders, aiming to analyze the gender differences on the incidence and on the determinants of the components of the frailty phenotype, most individuals found their own income to be insufficient, as was true in our study. Lower socioeconomic levels can limit the access to dietary, social, and health care. That may be the justification for the number of cases of malnutrition found.

With regards to the QoL domain of the caretaker, the highest score was found in the Social Relations domain, whose items investigate social relations, social support, and sexual activity. We can speculate that caregivers from this study received support from friends and relatives, since this helps strengthening partnerships and minimizes the difficulties inherent to the act of caring. Generally, the caregivers seemed satisfied with their QoL. This fact can be justified by the sample of the study, since the patients who were part of it did not have dementia and/or neurodegenerative diseases, could walk (even if with assistance) and were even able to do the gait speed test, thus filling very specific eligibility criteria.

As age increases, the chance of developing a frailty syndrome increases ${ }^{(28)}$, which can culminate in more chances of hospitalization, increased daily costs of care, and dependency ${ }^{(29)}$. This provision of care, in the long run, leads to physical and emotional overload, and may even lead to the surfacing of chronic diseases such as arthritis and peripheral vascular diseases ${ }^{(30)}$, changing, thus, aspects that are inherent to the quality of life of the caregiver. This confirms our results, according to which the more advanced the age, the greatest the negative impact on the Physical and General Quality of Life domains.

\section{Study limitations}

One limitation of this study was its cross-sectional design, which prevents the inference of causal relations. Another limitation was the fact that the interview with the caretaker was carried out in the first 48 hours after the admission of the patient, since, oftentimes, the patient only needs care during surgery or hospitalization.

\section{Contributions to the fields of Nursing, Health or Public Policy}

As contributions of this study, we highlight that this study can lead to the development of new researches that aim to strengthen the discussion about the theme discussed from a multimodal perspective. Therefore, this study will be able to aid in the formation of public policies targeted at caregivers, so that the health team is better trained and more attentive to them, carrying out actions and interventions targeted at this public so that the work of the caregiver is less arduous and aiding them to improve their own quality of life and the care they provide.

\section{CONCLUSION}

The age of the patient was a characteristic that was significantly related to the quality of life of the elder in the Physical domain. The gait speed of the patient, in turn, was related to the general quality of life of the caregivers. In the sample investigated, the nutritional status seemed to have no impact in the QoL of the of the caregiver, even considering the results of a BMI evaluation and the fact that most patients were malnourished, according to the PG-SGA. 


\section{REFERENCES}

1. United Nations. World Population Prospects 2019: Highlights. Department of Economic and Social Affairs [Internet]. 2019 [cited 2019 Sep 16]. Available from: https://population.un.org/wpp/Publications/Files/WPP2019_Highlights.pdf

2. Veras R, Oliveira M. Care pathway for the elderly: detailing the model. Rev Bras Geriatr Gerontol. 2016;19(6):887-905. doi: $10.1590 / 1981-22562016019.160205$

3. Fried LP, Tangen CM, Walston J, Newman AB, Hirsch C, Gottdiener J, et al. Frailty in older adults: evidence for a phenotype. J Gerontol Ser A Biol Sci Med Sci. 2001;56(3):146-56. doi: 10.1093/gerona/56.3.m146

4. Boulos C, Salameh P, Barberger-Gateau P. Malnutrition and frailty in community dwelling older adults living in a rural setting. Clin Nutr. 2016;35(1):138-43. doi: 10.1016/j.clnu.2015.01.008

5. Correia MITD, Perman MI, Waitzberg DL. Hospital malnutrition in Latin America: a systematic review. Clin Nutr. 2017;36(4):958-67. doi: 10.1016/j.clnu.2016.06.025

6. Cederholm T, Jensen GL, Correia MITD, Gonzalez MC, Fukushima R, Higashiguchi T, et al. GLIM criteria for the diagnosis of malnutrition: a consensus report from the global clinical nutrition community. Clin Nutr. 2019;38(1):1-9. doi: 10.1016/j.clnu.2018.08.002

7. Detsky AS, McLaughlin JR, Baker JP, Johnston N, Whittaker S, Mendelson RA, et al. What is subjective global assessment of nutritional status? JPEN J Parenter Enteral Nutr. 1987;11(1)8-13. doi: 10.1177/014860718701100108

8. Jager-Wittenaar H, Ottery FD. Assessing nutritional status in cancer: role of the patient-generated subjective global assessment. Curr Opin Clin Nutr Metab Care. 2017;20(5):322-9. doi: 10.1097/MCO.0000000000000389

9. Martinez BP, Batista AKMS, Ramos IR, Dantas JC, Gomes IB, Forgiarini LA, et al. Viabilidade do teste de velocidade de marcha em idosos hospitalizados. J Bras Pneumol. 2016;42(3):196-202. doi: 10.1590/S1806-37562015000000058

10. Cruz-Jentoft AJ, Bahat G, Bauer J, Boirie Y, Bruyère $O$, Cederholm T, et al. Sarcopenia: revised European consensus on definition and diagnosis. Age Ageing. 2019;48(1):16-31. doi: 10.1093/ageing/afy169

11. Waitzberg DL, Correia MI. Strategies for High-Quality Nutrition Therapy in Brazil. J Parenter Enter Nutr. 2015;40(1):73-82. doi: $10.1177 / 0148607115596159$

12. Velázquez-Alva MC, Irigoyen-Camacho ME, Zepeda-Zepeda MA, et al. Sarcopenia, nutritional status and type 2 diabetes mellitus: a crosssectional study in a group of Mexican women residing in a nursing home. Nutr Diet 2019. doi: 10.1111/1747-0080.12551

13. Studenski S, Faulkner K, Inzitari M, Brach J, Chandler J, Cawthon P, et al. Gait speed and survival in older adults. JAMA J Am Med Assoc. 2015;305(1):50-8. doi: 10.1001/jama.2010.1923

14. Guedes RC, Dias RC, Neri AL, Ferriolli E, Lourenço RA, Lustosa LP. Declínio da velocidade da marcha e desfechos de saúde em idosos: dados da Rede Fibra. Fisioter Pesqui. 2019;26(3)304-10. doi: 10.1590/1809-2950/18036026032019

15. Ministério da Saúde (BR). Guia Prático do Cuidador [Internet]. Ministério da Saúde. Brasília; 2008 [cited 2019 Sep 16]. 64 p. Available from: http://bvsms.saude.gov.br/bvs/publicacoes/guia_pratico_cuidador.pdf

16. Peres PA, Buchalla CM, Silva SM. Aspectos da sobrecarga e qualidade de vida de cuidadores de pacientes hospitalizados: uma análise baseada na Classificação Internacional de Funcionalidade, Incapacidade e Saúde (CIF). Rev Bras Saúde Ocup. 2018;6369:1-7. doi: $10.1590 / 2317-6369000013617$

17. Nunes DP, Brito TRP, Corona LP, Alexandre TS, Duarte YAO. Elderly and caregiver demand: proposal for a care need classification. Rev Bras Enferm. 2018;71(suppl 2):844-50. [Thematic Issue: Health of the Elderly]. doi: 10.1590/0034-7167-2017-0123

18. Fleck MP, Louzada S, Xavier M, Chachamovich E, Vieira G, Santos L, et al. Application of the Portuguese version of the abbreviated instrument of quality life WHOQOL-bref. Rev Saude Publica. 2000;34(2):178-83. doi: 10.1590/S0034-89102000000200012

19. Jesus ITM, Orlandi AAS, Zazzetta MS. Sobrecarga, perfil e cuidado: cuidadores de idosos em vulnerabilidade social. Rev Bras Geriatr e Gerontol. 2018;21(2):194-204. doi: 10.1590/1981-22562018021.170155

20. Associação Brasileira de Empresas de Pesquisa (ABEP). Critério de Classificação Econômica Brasil 2018 [Internet]. São Paulo: ABEP. 2018 [cited 2019 Oct 06]. Available from: http://www.abep.org/criterio-brasil

21. The World Health Organization Quality of Life Group. Development of the World Health Organization WHOQOL-BREF quality of life assessment. The WHOQOL Group. Psychol Med [Internet]. 1998 [cited 2019 Sep 20];28(3):551-8. Available from: https://pdfs.semanticscholar. org/e8ff/ae53509590129240f132b354ad36e649d6bd.pdf

22. World Health Organization-WHO. Physical status: the use and interpretation of anthropometry: report of a WHO Expert Committee [Internet]. Geneva: World Health Organization. 1995 [cited 2019 Oct 6]. Available from: http://www.who.int/childgrowth/publications/ physical_status/en/index.html

23. Lipschitz DA. Screening for nutritional status in the elderly. Prim Care [Internet]. 1994[cited 2019 Oct 06];21(1)55-67. Available from: https:// www.ncbi.nlm.nih.gov/pubmed/8197257

24. Gonzalez MC, Borges LR, Silveira DH, Assunção MCF, Orlandi SP. Validação da versão em português da avaliação subjetiva global produzida pelo paciente. Rev Bras Nutr Clin [Internet]. 2010[cited 2019 Oct 6];25(2):102-8. Available from: http://www.braspen.com.br/home/ 
wp-content/uploads/2016/12/02-Valida\%C3\%A7\%C3\%A3o-da-vers\%C3\%A3o-em-portugu\%C3\%AAs-da-avalia\%C3\%A7\%C3\%A3osubjetiva-global-produzida-pelo-paciente.pdf

25. Maggio M, Ceda GP, Ticinesi A, De Vita F, Gelmini G, Costantino C, et al. Instrumental and non-instrumental evaluation of 4-meter walking speed in older individuals. PLoS One. 2016;11(4):1-10. doi: 10.1371 / journal.pone.0153583

26. Kantorski LP, Jardim VMR, Treichel CAS, Andrade APM, Silva MSSJ, Coimbra VCC. Gênero como marcador das relações de cuidado informal em saúde mental. Cad Saúde Colet. 2019;27(1):60-6. doi: 10.1590/1414-462×201900010071

27. Alexandre TS, Corona LP, Brito TRP, Santos JLF, Duarte YAO, Lebrão ML. Gender differences in the incidence and determinants of components of the frailty phenotype among older adults: findings from the SABE Study. J Aging Health. 2018;30(2):190-212. doi: $10.1177 / 0898264316671228$

28. Duarte M, Paúl C. Prevalence of phenotypic frailty during the aging process in a Portuguese community. Rev Bras Geriatr Gerontol. 2015;18(4):871-80. doi: 10.1590/1809-9823.2015.14160

29. Butler A, Gallagher D, Gillespie P, Crosby L, Ryan D, Lacey L, et al. Frailty: a costly phenomenon in caring for elders with cognitive impairment. Int J Geriatr Psychiatry. 2016;31(2):161-8. doi: 10.1590/1809-9823.2015.14160

30. Brigola AG, Luchesi BM, Rossetti ES, Mioshi E, Inouye K, Pavarini SCI. Perfil de saúde de cuidadores familiares de idosos e sua relação com variáveis do cuidado: um estudo no contexto rural. Rev Bras Geriatr Gerontol. 2017;20(3): 410-422. doi: 10.1590/1981-22562017020.160202 